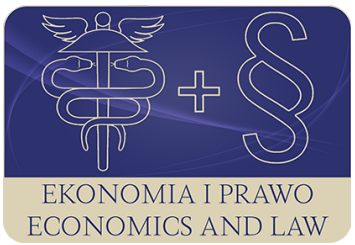

EKONOMIA I PRAWO. ECONOMICS AND LAW

Volume 20, Issue 4, December 2021

p-ISSN 1898-2255, e-ISSN 2392-1625

www.economicsandlaw.pl

ORIGINAL ARTICLE

received 31.05.2021; revised 01.12.2021; accepted 31.12.2021

Citation: Korkosz-Gębska, J. (2021). Selected aspects of the university social responsibility (USR)

in Poland. Ekonomia i Prawo. Economics and Law, 20(4), 835-845. https://doi.org/10.12775/EiP.2021.049.

\title{
Selected aspects of the university social responsibility (USR) in Poland
}

\author{
JOLANTA KORKOSZ-GĘBSKA
}

Warsaw University of Technology, Faculty of Mechanical and Industrial Engineering, Institute of Production Systems Organization, ul. Narbutta 86, 02-524 Warsaw, Poland

$\square$ jolanta.gebska@pw.edu.pl

(iD) orcid.org/0000-0002-0793-6253

\begin{abstract}
Motivation: In accordance with the Law on Higher Education, the mission of the Polish education and science system is to provide top quality education and scientific activity, develop civic attitudes, and be involved in social development and creation of an innovation-based economy. The third mission of an academy focusing on social responsibility is to build mutual relations with the community in order to popularise and implement research results. In recent years, university social responsibility (USR) has turned into one of the priorities for Polish academic authorities, although research shows this to be a new matter in this area, which often leads to incorrect classification of activities resulting from regular obedience of the law as activities confirming the social responsibility of the organisation.

Aim: The main objective of this article is to identify examples of socially responsible activity assumed by Polish academies and demonstrate the similarities with such activities conducted by other foreign academies. The author also wanted to associate the name of Professor Karol Adamiecki with social responsibility affairs what is usually overlooked in studies on this subject.

Results: The conducted analyses confirmed that Polish academies are assuming socially responsible activity voluntarily and not just in order to fulfil the criterion of conformity with the currently effective laws. Furthermore, these results also confirm that - in comparison with academies abroad — the involvement of Polish academies in implementation of the concept of social responsibility is on the right path of development, although not as popularised, which only confirms the genuine and non-marketing approach to the matter of social responsibility.
\end{abstract}


Keywords: university social responsibility; USR; third mission of an academy; ISO 26000:2010 JEL: Q01; I23; I25

\section{Introduction}

In recent years, matters related with education for social responsibility have considerably gained in popularity, although — when compared to foreign academies - they may be deemed as something completely new, which cannot be perceived outside of the very popular concept of corporate social responsibility (CSR). Although matters of business ethics were discussed all the way back in ancient times, the common belief is that the first scientific study on CSR appeared late in the 19th century. In his book The gospel of wealth, Andrew Carnegie included the classic definition of corporate social responsibility based on two principles (Stoner, 1999, p. 112):

- charity, also known as the philanthropy principle, according to which the weaker and more needy should be supported by the wealthy members of the community, e.g. in form of direct material and financial assistance, or by institutions such as nursing homes or churches;

- stewardship, also known as the trust principle, which comes from the Bible and requires the wealthy and enterprises to treat themselves only as caretakers of their property and to use it for the benefit of the entire community for only the purposes it deems legitimate.

Unfortunately, the literature on social responsibility tends to omit the name of the precursor of management sciences, Professor Karol Adamiecki, who was employed at the Warsaw University of Technology from 1919 and whose life "served as an example of extraordinary will to accomplish objectives in scope of the common good having nothing in common with the selfishness of the individual" (Stawiński, 1938, pp. 29-30). Adamiecki (1970, p. 110) believed that administrators of industrial plants should balance the results of the work in scope of other perspectives as well, i.e. in scope of the benefits for the given industrial plant, entire industry branches, employees, capital invested in the industrial plant, and the personal benefit of the administrator. He believed that "the general public balance stands above all said balances. As the citizens of a civilised country, we have no right to sum up the results of our work from any perspective when we ignore the interests of the general society".

Due to the fact that this researcher's attitude and body of work in scope of social responsibility has been subject to omission, this study focuses mainly on the Warsaw University of Technology as an academy, which - despite being focused on technology - has a rich history of contributions to the development of social responsibility. This choice is also supported by the fact that universities of technology have the potential to considerably raise the living conditions of the society with their scientific research and the implementation of its results in order to resolve major social problems. 


\section{Literature review}

The word "responsibility" can be defined in two opposite directions: as negative (restrictive) responsibility concerning mainly the past, which is a form of settlement for past actions, and as positive responsibility, which refers to the future and concerning taking responsibility for certain goods (Filek, 2006, p. 8).

The father of corporate social responsibility is believed to be Bowen et al. (2013, p. 6), the first to use the concept of "social responsibility" in his book entitled Social responsibilities of the businessman, defining it as "the obligations of businessmen to pursue those policies, to make those decisions, or to follow those lines of action that are desirable in terms of the objectives and values of our society".

The body of work of Drucker also played a major role in the development of CSR, specifically his book entitled The practice of management (released initially in 1954), in which Drucker $(1999$, p. 87) stressed the need for managers to analyse the impact of the conducted strategy on the society. In his opinion, "all business organisations are fully responsible for their impact on the local community and the communities, in which they operate".

The model of corporate social responsibility proposed by A.B. Carroll is similar to the pyramid of needs of Abraham Maslow and covers 4 domains of responsibility. According to A.B. Carroll, social responsibility is the sum of the following partial responsibilities: economic and legal (required by the society), ethical (expected by the society), and philanthropic (desired by the society) (Pinkston \& Carroll, 1996, pp. 199-206). In scope of economic responsibility, organisations want to preserve their competitive position and high level of operating efficiency. Legal responsibility involves obeying the law - e.g. the labour law - or business obligations (Adamczyk, 2009, p. 41).

Ethical responsibility means acting in accordance with ethical standards and social expectations usually covered in ethical programmes, including avoiding improper conduct and disclosing wrong practices. Philanthropic responsibility concerns actions taken in order to satisfy the demands of citizens and fulfil obligations resulting from being a part of the community (Rudnicka, 2013, p. $58)$.

The various interpretations of the concept of social responsibility led to development of standard ISO 26000, Guidance on social responsibility, aimed to promote awareness of social responsibility and make it easier for organisations to take actions contributing to sustainable development. In accordance with the standard, social responsibility is to be interpreted as "an organisation's responsibility for the impact of its decisions on the society and the environment through transparent and ethical conduct, which:

- contributes to sustainable development, including health and the welfare of society;

- takes into account the expectations of stakeholders; 
- is in compliance with applicable law and consistent with international norms of behaviour;

- is integrated throughout the organization and practised in its relationships" (International Organization for Standardization, 2010, p. 3).

Due to the considerable shift in the understanding of the role of an academy in the contemporary world, specifically in the context of the aforementioned third mission, the activities of such organisations in scope of social responsibility are drawing more and more attention. This is obviously tied to the concept of USR, especially in situations where an academy partners with a different organisation, which is required to limit its cooperation to socially responsible entities only. It is worth emphasizing that "USR can renew the traditional mission of universities to improve human quality of life and address societal needs" (Shek et al., 2017, p. 13).

\section{Methods}

This study applies the results of the questionnaire survey on education for social responsibility conducted at the Warsaw University of Technology. The research methods include participant observation. Two sources of information were used in the study with involvement of the Desk Research method: original (including data provided by academies) and secondary, which includes scientific and online publications. The publication was also made possible thanks to the author's involvement in the work of the Social Responsibility Group of the Warsaw University of Technology and the Working Group for Social Responsibility functioning at the Ministry of Development Funds and Regional Policy.

\section{Results}

According to the analysis of information on Polish education for social responsibility, the interest in such activity has risen in recent years, which is evidenced in e.g. the signing of the Declaration of Education for Social Responsibility by 83 entities and the activity of the aforementioned the Working Group. The Declaration consists of twelve principles covering various aspects of education operations, didactic activity, internal organisation, and dialogue with stakeholders. Each of the principles dictates expectations towards academies and signatories aimed at development of the given area of academic operations in the spirit of social responsibility (Wierzbowska, 2019, p. 6).

The Working Group for Social Responsibility of University defines education for social responsibility as a "strategic and systemic approach to administration of the academy and development of cooperation and dialogue with stakeholders to benefit sustainable development, formation of social attitudes and values, support for academic values and creation of new ideas, and preservation and development of scientific and didactic competences with impact on operating efficiency and innovation” (Kulczycka \& Pędziwiatr, 2019, p. 9). 
This definition refers to the aforementioned approach of standard ISO 26000. However, it should be noted that there is a considerable difference in the role being played by academies, which includes providing knowledge, creating conditions benefiting learning, and expanding cooperation with the social and economic community (Kulczycka \& Pędziwiatr, 2019, p. 9). "University Social Responsibility is the ability of the University to disseminate and implement a set of general principles and specific values, using 4 key processes: management, teaching, research and extension, through the provision of educational services and transfer knowledge following ethical principles, good governance, respect for the environment, social engagement and the promotion of Values" (Giuffre \& Ratto, 2014, p. 233).

In reference to the aforementioned definition, responsible social activity may include voluntary activity exceeding beyond the responsibilities dictated by the law.

\subsection{Results of the questionnaire survey conducted in the community of the Warsaw University of Technology}

The initial actions taken in scope of education for social responsibility after the Declaration was signed included the survey conducted in late 2019 by the Department of Research and Analyses of the Centre for Innovation and Technology Transfer Management (CITTM), which covered 582 individuals representing students, doctoral candidates, and employees (both academic teachers and administration workers). The survey was conducted through an online questionnaire in a computer system (CAWI), was displayed on the respondent's device, and included both open-ended and closed-ended questions (Parzych et al., 2019 , p. 5). The invitation to take part in the survey was broadcast on social networking sites on the profiles of CITTM and student organizations.

The respondents established that the most important matters in scope of social responsibility concern ethical and responsible teaching $(76.8 \%$ of the respondents) as well as clear and transparent academic organisation (71\%). Over 3/5 of respondents pointed to research as an important aspect in the context of education for social responsibility. This is associated with research and development activity, which helps grow economic innovation (62\%), ethical and responsible research activity (61.3\%), and promotion of science in the society $(56.4 \%)$. A considerable part of the respondents also sees social responsibility in preserving social attitudes (55.7\%) and tolerance (50.5\%). The following statements were also important in the context of social responsibility: raising qualifications of the academic staff (60.5\%), ensuring equal access to education services (59.5\%), and adapting curricula to the demands of the labour market (53.4\%). The following statements were made by less than $1 / 3$ of the respondent: involvement in e.g. volunteer or charity activity, activity supporting culture, arts, and sports, and dialogue with university recruits (Parzych et al., 2019, p. 11). 


\subsection{Socially responsible activity of the Warsaw University of Technology}

In analysis of the relevant activity of the Warsaw University of Technology, we should note the numerous initiatives taken after the signing of the declaration. One of them was appointment of the Social Responsibility Group, the main assignment of which was to develop a Social Responsibility Strategy for the Warsaw University of Technology, as well as (Rector's decision, 2020):

- identifying and defining specific areas and activities composing the social responsibility mission of the Warsaw University of Technology;

- developing communication channels and instruments to allow for active involvement of the academic community of the Warsaw University of Technology in development of the education for social responsibility mission;

- consulting in implementation of good operating practices of organisational entities of the Warsaw University of Technology to ensure development in scope of education for social responsibility;

- supporting socially responsible initiatives assumed by members of the Warsaw University of Technology community;

- developing guidelines aimed to prevent undesirable situations such as mobbing, discrimination, and molestation;

- monitoring the effects of good practices implementation and organised initiatives and taking potential corrective measures;

- obtaining, analysing, and presenting data on fulfilment of the social responsibility mission of the Warsaw University of Technology.

In June 2021, the Senate of WUT adopted the strategy while in November 2021 the group was transformed into a Rector's Commission for Social Responsibility.

The COVID-19 was a major test for education for social responsibility. From the start of its outbreak, the University tended to the mental comfort of its students, doctoral candidates, and staff by organising cyclical meetings with the vice rector for student affairs, who provided ongoing information on the made decisions and directions of future actions. During this time, in addition to the focus on ensuring the entity's operations, numerous online events were organised in order to integrate the entire community. They included the quiz of knowledge about the Warsaw University of Technology, initiation of the series of meetings with members of the Warsaw University of Technology community who have interesting and unique interests, and organisation of webinars on the environmental effects of the pandemic. The organisational structure of the Warsaw University of Technology underwent modifications, specifically including appointment of new liaisons and representatives of the rector in charge of equal rights and development of a cohesive organisational culture.

It should be noted that the Warsaw University of Technology was "socially" active before it signed the declaration or before the outbreak of the pandemic. This activity included the series of concerts entitled Grand music in the small au- 
ditorium, opening of the "Bobotechnika" kindergarten, and the participation budget, which is a part of the University's budget with goals determined collectively by the students, doctoral candidates, and staff of the Warsaw University of Technology by vote of the academic community.

From the perspective of the impact of research on raising the living conditions of the society and resolving social problems we should note research on the COVID-19 vaccine, application of the fast prototyping technology and CAD/CAM methods supported by image analyses and durability calculations in development of new elements of machinery and biomedical products, surgery planning, or innovative solutions in scope of application of biodegradable moulding and core masses conducted by the Moulding Material Laboratory of the Faculty of Production Engineering. Other noteworthy examples in scope of USR include the following projects (Resolution No. 113/L/2021, 2021):

- MOGLiS - scientific support for low-emissions economy;

- "Polymer composites with elevated mechanical and electrical properties based on an innovative thermoplastic resin";

- Masovian platform of material and sensory technologies and applications in conversion and storage of energy, electromobility, aviation, and autonomous systems;

- "The Warsaw University of Technology as the Ambassador of Innovation for Availability";

- "Education for social responsibility — from promotion to social innovations";

- "Intellectual and social activation for seniors" and the broad employee competence development programme carried out in scope of projects such as NERW and NERW 2 (Science-Education-Development-Cooperation).

These activities were compared with examples of social responsibility activity of a non-technology academy. Selected social responsibility activity of the Warsaw School of Economics (2021) includes the following:

- launch of the University of the Third Age, the Economic University for Children, the Business Olympics;

- accession to Principles for Responsible Management Education;

- signing of the Declaration of Education for Social Responsibility;

- activation of the employee and student-doctoral candidate participation budget;

- appointment of the Chancellor's Committee for Social Responsibility of the Warsaw School of Economics;

- launch of intercollegiate rector's grants dedicated to USR;

- participative development and adoption of the Code of Ethic for employees of the Warsaw School of Economics;

- introduction of the mandatory "Corporate Social Responsibility" e-learning course for undergraduate students;

- signing of the Diversity Card.

Comparison of the social responsibility activity of these two academies shows numerous similar initiatives. A technology university definitely has the advan- 
tage in the conducted science research, which supports the operations of numerous sectors of the economy with particular consideration of the health care sector.

\subsection{Social responsibility of Polish academies in light of foreign academies}

Examples of USR activity are published in the Catalogue of Good Practices of the aforementioned Working Group for Social Responsibility of University. The Group's other initiatives, e.g. organisation of the "Academic Responsibility and Freedom" seminar or the Declaration of education for social responsibility implementation report as a tool for self-assessment webinar and the cyclical meetings of its members, create the opportunity for sharing mutual experiences in scope of implementation of the declaration's principles.

According to analyses of the reported practices, we can definitely say that the social responsibility activity of Polish academies somewhat departs from that of foreign academies and is not promoted to the same degree (from the marketing point of view). As an excuse, we can say that they are currently on the right path of development. Emphasizing activity in the area of the social responsibility is typical of foreign universities, especially those associated in the USR Network (2021) whose mission is to:

- "provide a platform for exchange of ideas, resources, policies, practices, problems and solutions to foster USR among member institutions;

- develop collaborative USR projects with varied scopes and scales within the Network;

- contribute to the global discussions and development of USR through networking and partnership within the Network, as well as with other networks and alliances".

The members of the network are 19 institutions from different regions of the world, such as Australia, Brazil, Canada, USA, China, Japan, Israel, United Kingdom, South Africa, etc. Among the members there are no representatives from Poland.

Certain foreign academies establish special cells to fulfil the objectives of sustainable development. They include the University of Arkansas or Uppsala University and its Centre for Research Ethics \& Bioethics (CRB). The University of Manchester takes special care of relations with local suppliers from the Greater Manchester agglomeration by organising e.g. Meet the Buyer events and operating a website for companies, which want to do business with the academy. The University of Manchester runs a "Social Responsibility Website" where posts information about events and activities related to USR.

Social responsibility also involves "minor activities" (but very important) such as those conducted by the University of Kent, which enforces a no smoking policy in all its buildings and within a 5-metre closed area outside of every building with consideration of the health of its students and staff. 
It should be noted that social responsibility has a longer history in foreign academies, which brings hope for Polish academies to make everything up with activity as intense as at present time. This will also result from the responsibilities towards partner academies and initiatives performed collectively, including e.g. the ENHANCE consortium, which is composed of 7 leading European universities of technology: TU Berlin, the RWTH Aachen University, the Chalmers University of Technology in Gothenburg, the Norwegian University of Science and Technology in Trondheim, Politecnico di Milano, Universitat Politècnica de València, and the Warsaw University of Technology. The activities of the ENHANCE consortium are funded by the European Commission under the ERASMUS+ programme for European Universities. The aim of the European Universities is to "create innovative networks of European universities that will increase the mobility of students and staff, develop innovative forms of education and engage the public" (ENHANCE, 2021). The mission of ENHANCE (2021) is to "strive for responsible social transformation, while the aim of the alliance is to use science and technology for the benefit of society to transform global challenges into development opportunities". The four main areas of the project are (ENHANCE, 2021):

- sustainable development through transdisciplinary research;

- sustainable entrepreneurship and innovation ecosystems;

- human resource (HR) development;

- research infrastructure.

Among the numerous activities carried out as part of the consortium, it is worth mentioning "Green Campus: ENHANCE summer school on climate change", organised by the WUT between 15th and 28th September 2021. As part of this summer school, students worked in interdisciplinary groups to develop green campus projects that were presented at the end of the summer school. The consortium will undertake a number of initiatives focusing on supporting people from disadvantaged groups, including those with disabilities, students from less economically developed regions, or students from families where no one has previously completed higher education (the so-called "first generation students").

\section{Conclusion}

According to the listed examples of activity taken by Polish academies in scope of social responsibility, said activity is not limited to that aimed only to fulfil the conformity with the currently effective laws but are often voluntary and exceed beyond the responsibilities established by the law. Although the signing of the Declaration of Education for Social Responsibility by academic authorities was voluntary, it must definitely be deemed as expected activity in light of the expectations of their stakeholders. This can be considered as the beginning of the socially responsible path that modern universities should follow to meet the emerging challenges supporting sustainable development, but also 
to meet the expectations set for universities in the third mission defined for this type of organisations.

In certain instances, the activity of foreign academies in scope of implementation of the concept of education for social responsibility is more advanced, but this situation may quickly improve due to the current intensification of activity among Polish academies. However, we need to remember the history and body of work of our own Polish researchers such as Professor Karol Adamiecki, especially when they concern social responsibility.

\section{References}

Adamczyk, J. (2009). Społeczna odpowiedzialność przedsiębiorstw. PWE. Adamiecki, K. (1970). O nauce organizacji: wybór pism. PWE.

Bowen, H.R., Gond, J.P., \& Bowen, P.G. (2013). Social responsibilities of the businessman. University of Iowa Press.

Decyzja Rektora nr 41/2020 z dnia 28.02.2020 w sprawie powołania Zespołu ds. społecznej odpowiedzialności Politechniki Warszawskiej [Rector's decision No. 41/2020 of 28.02.2020 on the establishment of the Social Responsibility Group of the Warsaw University of Technology]. Retrieved 27.05.2021 from https://www.bip.pw.edu.pl/Wewnetrzne-akty-prawne/Dokumenty-Rektora-PW/Decyzje-Rektora/2020 / Decyzja-Rektora-nr-41-2020-z-dnia-28-02-2020.

Drucker, P.F. (1999). Spoteczeństwo kapitalistyczne. PWN.

ENHANCE. (2021). About us. Retrieved 05.12.2021 from https://enhanceuniversity.eu/about-us.

Filek, J. (2006). Spoteczna odpowiedzialność biznesu: tylko moda czy nowy model prowadzenia dziatalności gospodarczej. UOKiK.

Giuffre, L. \& Ratto, S.E. (2014). A new paradigm in higher education: university social responsibility. Journal of Education \& Human Development, 3(1), 231-238.

International Organization for Standardization. (2010). Guidance on social responsibility. Retrieved 27.05.2021 from https://iso26000.info/wp-content/ uploads/2017/06/ISO-26000_2010_E_OBPpages.pdf.

Kulczycka, J., \& Pędziwiatr, E. (2019). Definicje SOU. In E. Jastrzębska, \& M. Przybysz (Eds.), Spoteczna odpowiedzialność: znaczenie dla uczelni $i$ sposoby wdrażania (pp. 9-10). Ministerstwo Nauki i Szkolnictwa Wyższego, Ministerstwo Inwestycji i Rozwoju.

Parzych, D., Płaszczyca, M., \& Zgutka, M. (2019). Wyniki badania \#powiedz PW: spoteczna odpowiedzialność uczelni. Retrieved 27.05.2021 from https://www.pw.edu.pl/Aktualnosci/ Wyniki-sondazu-PowiedzPW-Spoleczna-odpowiedzialnosc-uczelni.

Pinkston, T.S. \& Carroll, A.B. (1996). A retrospective examination of CSR orientations: have they changed. Journal of Business Ethics, 15(2), 199-206. https://doi.org/10.1007/bf00705587. 
Rudnicka, A. (2012). CSR: doskonalenie relacji spotecznych $w$ firmach. Wolters Kluwer.

Shek, D.T.L., Yuen-Tsang, A.W.K., \& Ng, E.C.W. (2017). USR network: a platform to promote university social responsibility. In D. Shek, \& R. Hollister (Eds.), University social responsibility and quality of life (pp. 11-21). Springer. https://doi.org/10.1007/978-981-10-3877-8_2.

Sławiński, Z. (1938). O Adamieckim zamiast przedmowy. In K. Adamiecki, O istocie naukowej organizacji (pp. 26-30). Zakłady Drukarskie „Drukarnia Krajowa".

Stoner, J.A.F., Freeman, R.E., \& Gilbert, D.R. (1999). Kierowanie. PWE.

Uchwała nr 113/L/2021 Senatu Politechniki Warszawskiej z dnia 23 czerwca 2021 r. w sprawie przyjęcia Strategii Społecznej Odpowiedzialności Politechniki Warszawskiejdoroku2030[ResolutionNo.113/L/2021 oftheSenateoftheWarsaw University of Technology of June 23, 2021 on the adoption of the Warsaw University of Technology Social Responsibility Strategy until 2030]. Retrieved 05.12.2021 from https://www.bip.pw.edu.pl/Wewnetrzne-akty-prawne/Dokumenty-Senatu-PW/Uchwaly-Senatu-PW/2021-L/ Uchwala-nr-113-L-2021-z-dnia-23-06-2021.

USR Network. (2021). Mission. Retrieved 06.12.2021 from https://www.usrnetwork.org/about-usrn/vision-mission.

Warsaw School of Economics. (2021). Dziatania SGH na rzecz SOU. Retrieved 27.05.2021 from https://ssl-uczelnia.sgh.waw.pl/pl/sou/Strony/default. aspx.

Wierzbowska, D. (2019). Deklaracja Społecznej Odpowiedzialności. In E. Jastrzębska, \& M. Przybysz (Eds.), Społeczna odpowiedzialność: znaczenie dla uczelni i sposoby wdrażania (pp. 6-8). Ministerstwo Nauki i Szkolnictwa Wyższego, Ministerstwo Inwestycji i Rozwoju.

\section{Acknowledgements}

Author contributions: author has given an approval to the final version of the article.

Funding: this research was fully funded by the Warsaw University of Technology.

Supplementary information: author acknowledge following people and institution for help with the preparation of the article: the Social Responsibility Group (J. Walo, A. Bartnik, P. Chrobocińska, A. Cieśla, K. Gęca, L. Hawrysz, A. Kamińska, A. Manujło, I. KoptońRyniec, U. Okulska-Deblessem, R. Piramidowicz, M. Sidor-Rządkowska, R. Walczak, A. Rogowska, P. Szrajber) and the Internal Audit Team (A. Myrcha, J. Zastawna).

Note: the results of this study were presented at the 8th International Conference Sustainable Finance \& Accounting: Economy, Ethics, Environment (April 19-21, 2021, Toruń, Poland). 
